\title{
Cytotoxicity and anti-HIV evaluations of some new synthesized quinazoline and thioxopyrimidine derivatives using 4-(thiophen-2-yl)-3,4,5,6-tetrahydrobenzo[h]quinazoline-2(1H)-thione as synthon
}

\author{
YAHIA A MOHAMED ${ }^{\mathrm{a}}$, ABD EL-GALIL E AMR ${ }^{\mathrm{b}, \mathrm{c}, *}$, SALWA F MOHAMED $^{\mathrm{c}}$, \\ MOHAMED M ABDALLA ${ }^{\mathrm{d}}$, MOHAMED A AL-OMAR ${ }^{\mathrm{e}}$ and SAMIRA H SHFIK \\ ${ }^{a}$ Chemistry Department, Faculty of Science, El-Azhar University, Cairo 11787, Egypt \\ ${ }^{b}$ Drug Exploration and Development Chair (DEDC), College of Pharmacy, King Saud University, \\ Riyadh 11451, Saudi Arabia \\ ${ }^{\mathrm{c}}$ Applied Organic Chemistry Department, National Research Centre, Dokki, Cairo 12622, Egypt \\ ${ }^{\mathrm{d}}$ Research Unit, Saco Pharm. Co., 6th October City, Cairo 15324, Egypt \\ ePharmaceutical Chemistry Department, College of Pharmacy, King Saud University, Riyadh 11451, \\ Saudi Arabia \\ e-mail: aamr1963@yahoo.com
}

MS received 24 April 2011; revised 14 September 2011; accepted 22 November 2011

\begin{abstract}
A series of dihydrobenzo[h]quinazoline derivatives 5-19 were synthesized using arylmethylene 2, thiopyrimidine 3 and 2-(4-(thiophen-2-yl)-5,6-dihydrobenzo[h]quinazolin-2-ylthio) acetic acid (4) as a starting materials. The biological screening showed that many of these compounds have good anticancer and antiviral activities. The structure assignments of the new compounds based on chemical and spectroscopic evidence. The detailed synthesis, spectroscopic data, and pharmacological properties are reported.
\end{abstract}

Keywords. Arylmethylene; thiopyrimidine; dihydrobenzo[h]quinazolin-2-ylthioacetic acid; anticancer; antiviral and cytotoxic evaluations.

\section{Introduction}

The pyrimidinoyl and thioxopyrimidinoyl groups are of great importance in treating biological system. Analgesic, anti-arrhythmic, anticancer, antipyretic and anti-inflammatory activities are observed in some pyrimidinoyl and thioxopyrimidinoyl derivatives. ${ }^{1-5}$ Also, in our previous work we prepared certain new substituted heterocyclic derivatives which exhibit analgesic, anti-inflammatory, antiparkinsonian, and androgenic-anabolic activities. ${ }^{6-11}$ In addition, the heterocyclic nitrogen derivatives exhibited a general ionophoric potency for divalent cations ${ }^{12}$ and used a novel thiocyanate-selective membrane sensor. ${ }^{13}$ Recently, anticancer and biological screening for some of synthesized heterocyclic compounds was reported. ${ }^{14-19}$ In view of these observations and in continuation of our previous work in heterocyclic chemistry, we have synthesized here of some new

*For correspondence derivatives containing quinazoline moiety. Some of the synthesized compounds were screened for their anticancer and antiviral activities due to structure similarity between our newly synthesized compounds and a clinically used agents in these fields.

\section{Experimental}

\subsection{Chemistry}

Melting points were determined on open glass capillaries using an Electrothermal IA 9000 digital melting point apparatus. Elemental analyses were performed on Elementar, Vario EL, Microanalytical Unit, National Research Center, Cairo, Egypt and were found within $\pm 0.4 \%$ of the theoretical values. Infrared spectra were recorded on Carlzeise Spectrophotometer model "UR 10 " spectrophotometer using the $\mathrm{KBr}$ disc technique. ${ }^{1} \mathrm{H}-\mathrm{NMR}$ spectra were recorded on Varian Gemini $270 \mathrm{MHz}$ spectrometer (DMSO- $\mathrm{d}_{6}$ ) and the chemical shifts are given in $\delta(\mathrm{ppm})$ downfield from tetramethylsilane (TMS) as an internal standard. The mass spectra 
were measured using a Finnigan SSQ 7000 mass spectrometer. Follow up of the reactions and checking the purity of the compounds was made by TLC on silica gel-aluminum sheets (Type $60 \mathrm{~F}_{254}$, Merck, Darmstadt, Germany).

\section{1a 4-(Thiophen-2-yl)-5,6-dihydrobenzo[h]quinazo-} lin-2-amine (5): To a boiling solution of compound 2 $(2.4 \mathrm{~g}, 0.01 \mathrm{~mol})$ in ethanolic potassium hydroxide $(100 \mathrm{ml}, 1 \%)$, guanidine hydrochloride $(0.95 \mathrm{~g}$, $0.01 \mathrm{~mol}$ ) was added. The reaction mixture was refluxed for $5 \mathrm{~h}$, then allowed to cool and the solid formed was filtered off, dried and crystallized to give compound 5 in yield: $83 \%$; m.p: $220^{\circ} \mathrm{C}(\mathrm{EtOH})$; IR $(\mathrm{KBr}) v_{\max }$ : $3314,3209 \mathrm{~cm}^{-1}\left(\mathrm{NH}_{2}\right)$. The IR spectrum is also devoid of the band corresponding to $v(\mathrm{C}=\mathrm{O})$ present in the IR spectrum of $2 .{ }^{1} \mathrm{H}$ NMR $\left(270 \mathrm{MHz}, \mathrm{DMSO}-d_{6}\right): \delta$ 2.84, $2.97\left(2 \mathrm{t}, 4 \mathrm{H}, 2 \mathrm{CH}_{2}\right.$ of quinazoline ring), 6.56 (s, $2 \mathrm{H}, \mathrm{NH}_{2}, \mathrm{D}_{2} \mathrm{O}$ exchangeable) 7.17-7.75 (m, 6H, Ar-H + thiophene-H), $8.12\left(\mathrm{~d}, 1 \mathrm{H}, \mathrm{C}_{5}\right.$-thiophene). MS $\mathrm{m} / \mathrm{z}$ (\%): $281\left(\mathrm{M}^{+}+2,100\right)$ corresponding to the molecular formula $\mathrm{C}_{16} \mathrm{H}_{13} \mathrm{~N}_{3} \mathrm{~S}$. Analysis: Calcd. C, 68.79; $\mathrm{H}, 4.69$; N, 15.04; S, 11.48. Found C, 68.74;H, 4.65; N, 14.98; S, 11.43.

$2.1 \mathrm{~b}$ 4,5,6,7-Tetrachloro-2-(4-thiophen-2-yl-3,4,5,6tetrahydro-benzo[h]quinazolin-2-yl)-isoindole-1,3-dione (6): A mixture of $5(2.79 \mathrm{~g}, 0.01 \mathrm{~mol})$ and 3,4,5,6tetrachlorophthalic anhydride $(2.85 \mathrm{~g}, 0.01 \mathrm{~mol})$ was heated under fusion condition for $0.5 \mathrm{~h}$., left to cool. The residue was triturated with ethanol and the obtained solid was filtered off, dried and crystallized to give compound 6 in yield: $61 \%$; m.p: $252^{\circ} \mathrm{C}(\mathrm{AcOH})$; IR $(\mathrm{KBr}) v_{\max }: 1737 \mathrm{~cm}^{-1}$ corresponding to $v(\mathrm{C}=\mathrm{O}) .{ }^{1} \mathrm{H}$ NMR $\left(270 \mathrm{MHz}\right.$, DMSO- $\left.d_{6}\right): \delta 3.00-3.10(\mathrm{~m}, 4 \mathrm{H}$, $2 \mathrm{CH}_{2}$ of quinazoline $), 7.30-8.20(\mathrm{~m}, 11 \mathrm{H}, \mathrm{Ar}-\mathrm{H}+$ thiophene-H). MS $m / z$ (\%): $547\left(\mathrm{M}^{+}, 27\right)$ corresponding to the molecular formula $\mathrm{C}_{24} \mathrm{H}_{11} \mathrm{Cl}_{4} \mathrm{~N}_{3} \mathrm{O}_{2} \mathrm{~S}$ and base peak at m/z 546 (100); Analysis: Calcd. C, 52.67; H, 2.03; Cl, 25.91; N, 7.68; S, 5.86. Found C, 52.61; H, 1.95; Cl, 25.86; N, 7.61; S, 5.78.

2.1c N-(4-(Thiophen-2-yl)-5,6-dihydrobenzo[h]quinazolin-2-yl)acetamide (7): A solution of 5 (2.79g, $0.01 \mathrm{~mol})$ in acetic anhydride $(10 \mathrm{ml})$ was heated refluxed for $2 \mathrm{~h}$. After cooling, the reaction mixture was poured onto ice water. The separated solid was collected by filtration, washed with water, dried and crystallized to give compound 7 , in yield: $72 \%$; mp: $115^{\circ} \mathrm{C}(\mathrm{EtOH})$; IR $(\mathrm{KBr}) v_{\max }: 3207$ and $1661 \mathrm{~cm}^{-1}$ corresponding to $v(\mathrm{NH})$ and $v(\mathrm{C}=\mathrm{O})$, respectively. ${ }^{1} \mathrm{H}$
NMR $\left(270 \mathrm{MHz}, \mathrm{DMSO}-d_{6}\right): \delta 1.91\left(\mathrm{~s}, 3 \mathrm{H}, \mathrm{CH}_{3}\right), 2.94$, $3.18\left(2 \mathrm{t}, 4 \mathrm{H}, 2 \mathrm{CH}_{2}\right.$ of quinazoline ring), 7.27-8.10 (m, 7H, Ar-H + thiophene-H), $10.38\left(\mathrm{~s}, 1 \mathrm{H}, \mathrm{NH}, \mathrm{D}_{2} \mathrm{O}\right.$ exchangeable). MS $m / z(\%): 321\left(\mathrm{M}^{+}, 100\right)$; Analysis for $\mathrm{C}_{18} \mathrm{H}_{15} \mathrm{~N}_{3} \mathrm{OS}$ : Calcd. C, 67.27; H, 4.70; N, 13.07; S, 9.98. Found C, 67.23; H, 4.65; N, 13.03; S, 9.92.

2.1d N-(4-(Thiophen-2-yl)-5,6-dihydrobenzo[h]quinazolin-2-yl)methanesulphonamide (8): A mixture of compound $5(2.79 \mathrm{~g}, 0.01 \mathrm{~mol})$ and methylsulphonylchloride $(1.14 \mathrm{~g}, 0.01 \mathrm{~mol})$ in dry pyridine $(20 \mathrm{ml})$ was heated at $70-75^{\circ} \mathrm{C}$ on a waterbath for $4 \mathrm{~h}$. After cooling, the reaction mixture was acidified with diluted hydrochloric acid and the obtained solid was filtered off, washed with hot water, dried and crystallized to give compound 8 in yield: $67 \%$; mp: $145^{\circ} \mathrm{C}(\mathrm{EtOH})$; IR $(\mathrm{KBr}) v_{\max }: 3344 \mathrm{~cm}^{-1}$ corresponding to $v(\mathrm{NH})$. ${ }^{1} \mathrm{H}$ NMR $\left(270 \mathrm{MHz}\right.$, DMSO- $\left.d_{6}\right): \delta 2.94-3.13(2 \mathrm{t}, 4 \mathrm{H}$, $2 \mathrm{CH}_{2}$ of quinazoline ring), $3.57\left(\mathrm{~s}, 3 \mathrm{H}, \mathrm{CH}_{3}\right), 7.27-$ $7.84(\mathrm{~m}, 6 \mathrm{H}, \mathrm{Ar}-\mathrm{H}+$ thiophene $), 8.15\left(\mathrm{~d}, 1 \mathrm{H}, \mathrm{C}_{5}\right.$ thiophene), 11.18 (s, $1 \mathrm{H}, \mathrm{NH}, \mathrm{D}_{2} \mathrm{O}$ exchangeable). MS $m / z(\%): 357\left(\mathrm{M}^{+}, 100\right)$ corresponding the molecular formula $\mathrm{C}_{17} \mathrm{H}_{15} \mathrm{~N}_{3} \mathrm{O}_{2} \mathrm{~S}_{2}$; Analysis: Calcd. C, 57.12; $\mathrm{H}$, 4.23 ; N, 11.76; S, 17.94. Found C, 57.06; H, 4.15; N, $11.70 ; \mathrm{S}, 17.88$.

2.1e 4-(Thiophen-2-yl)-5,6-dihydrobenzo[h]quinazoline-2(1H)-thione (9): A mixture of compound 3 $(2.98 \mathrm{~g}, 0.01 \mathrm{~mol})$ and sodium hydride $(0.8 \mathrm{~g}, 0.02 \mathrm{~mol})$ in dimethylformamide $(40 \mathrm{ml})$ was stirred at $70-80^{\circ} \mathrm{C}$ for $1 \mathrm{~h}$. then cooled to room temperature, chlorodiethyl ether $(1 \mathrm{~g}, 0.01 \mathrm{~mol})$ was added and heated at $90^{\circ} \mathrm{C}$ for $5 \mathrm{~h}$. The reaction mixture was evaporated under reduced pressure, the obtained residue was triturated with water and the obtained solid was filtered off, dried and crystallized to give compound $\mathbf{9}$ in yield: 72\%; m.p: $220^{\circ} \mathrm{C}(\mathrm{EtOH})$; IR (KBr) $v_{\max }$ : $3416(\mathrm{NH})$, $1189 \mathrm{~cm}^{-1}(\mathrm{C}=\mathrm{S}) ;{ }^{1} \mathrm{H}$ NMR $\left(270 \mathrm{MHz}, \mathrm{DMSO}-d_{6}\right)$ : $\delta 2.70,3.20\left(2 \mathrm{t}, 4 \mathrm{H}, 2 \mathrm{CH}_{2}\right.$ of quinazoline $), 7.00-8.10$ $\left(\mathrm{m}, 7 \mathrm{H}, \mathrm{Ar}-\mathrm{H}+\right.$ thiophene), $8.54\left(\mathrm{~s}, 1 \mathrm{H}, \mathrm{NH}, \mathrm{D}_{2} \mathrm{O}\right.$ exchangeable). MS $m / z(\%): 296\left(\mathrm{M}^{+}, 95\right)$ corresponding the molecular formula $\mathrm{C}_{16} \mathrm{H}_{12} \mathrm{~N}_{2} \mathrm{~S}_{2}$ and base peak at 238 (100); Analysis: Calcd. C, 64.83; H, 4.08; N, 9.45; S, 21.64.Found C, 64.76; H, 4.03; N, 9.39; S, 21.58.

2.1f 1-(4-(Thiophen-2-yl)-2-thioxo-1,2,5,6-tetrahydrobenzo[h]quinazolin-3(4H)-yl)ethanone (11): A mixture of compound $\mathbf{3}$ (2.98 g, $0.01 \mathrm{~mol})$, acetylchloride $(0.78 \mathrm{~g}, 0.01 \mathrm{~mol})$ in pyridine $(30 \mathrm{ml})$ was refluxed for $2 \mathrm{~h}$. The reaction mixture was poured onto acidified water $(\mathrm{pH} \sim 3)$, the solid formed was filtered off, 
washed with water, dried and crystallized to give compound 11 in yield: $60 \%$; m.p: $195^{\circ} \mathrm{C}(\mathrm{AcOH})$; IR $(\mathrm{KBr})$ $v_{\max }: 3257$ and $1671 \mathrm{~cm}^{-1}$ corresponding to $v(\mathrm{NH})$ and $v\left(\mathrm{C}=\mathrm{O}\right.$, acetyl), respectively. ${ }^{1} \mathrm{H}$ NMR $(270 \mathrm{MHz}$, DMSO- $\left.d_{6}\right): \delta 2.30-2.90\left(\mathrm{~m}, 7 \mathrm{H}, 2 \mathrm{CH}_{2}+\mathrm{CH}_{3}\right), 6.10(\mathrm{~s}$, $1 \mathrm{H}, \mathrm{CH}$ of pyrimidine proton), $7.00-7.70(\mathrm{~m}, 7 \mathrm{H}, \mathrm{Ar}-$ $\mathrm{H}+$ thiophene- $\mathrm{H}), 11.80\left(\mathrm{~s}, 1 \mathrm{H}, \mathrm{NH}, \mathrm{D}_{2} \mathrm{O}\right.$ exchangeable). MS $m / z(\%): 340\left(\mathrm{M}^{+}, 10\right)$ corresponding the molecular formula $\mathrm{C}_{18} \mathrm{H}_{16} \mathrm{~N}_{2} \mathrm{OS}_{2}$ and base peak at 297 (100); Analysis: Calcd. C, 63.50; H, 4.74; N, 8.23; S, 18.84. Found C, 63.46; H, 4.69; N, 8.17; S,18.68.

2.1g S-[4-(Thiophen-2-yl)-3,4,5,6-tetrahydrobenzo[h]quinazolin-2-yl]-2-chloroethanethioate (12): A mixture of $3(2.98 \mathrm{~g}, 0.01 \mathrm{~mol})$ and chloroacetylchloride $(1.12 \mathrm{~g}, 0.01 \mathrm{~mol})$ in dry acetone $(50 \mathrm{ml})$ in the presence of anhydrous $\mathrm{K}_{2} \mathrm{CO}_{3}(2.76 \mathrm{~g}, 0.02 \mathrm{~mol})$ was refluxed on a waterbath for $24 \mathrm{~h}$. The reaction mixture was evaporated under reduced pressure and the residue was triturated with water. The separated solid was filtered off, washed with water, dried and crystallized to give compound 12 in yield: $71 \%$; m.p: $175^{\circ} \mathrm{C}(\mathrm{MeOH})$; IR $(\mathrm{KBr}) v_{\max }: 1721 \mathrm{~cm}^{-1}$ corresponding to $v(\mathrm{C}=\mathrm{O})$. IR spectrum taken as representative was devoid of bands corresponding to $v(\mathrm{NH})$ and $v(\mathrm{C}=\mathrm{S})$ present in spectrum of the parent compound 3. ${ }^{1} \mathrm{H}$ NMR $(270 \mathrm{MHz}$, DMSO- $\left.d_{6}\right): \delta 1.90,2.70\left(2 \mathrm{t}, 4 \mathrm{H}, 2 \mathrm{CH}_{2}\right.$ of quinazoline ring), $4.10\left(\mathrm{~s}, 2 \mathrm{H}, \mathrm{CH}_{2}\right), 6.00(\mathrm{~s}, 1 \mathrm{H}, \mathrm{CH}$ of pyrimidine proton), 6.90-7.80 (m, $7 \mathrm{H}, \mathrm{Ar}-\mathrm{H}+$ thiophene-H) and $12.00\left(\mathrm{~s}, 1 \mathrm{H}, \mathrm{NH}, \mathrm{D}_{2} \mathrm{O}\right.$ exchangeable). $\mathrm{MS} \mathrm{m} / z(\%)$ : $374\left(\mathrm{M}^{+}, 15\right)$ corresponding the molecular formula $\mathrm{C}_{18} \mathrm{H}_{15} \mathrm{ClN}_{2} \mathrm{OS}_{2}$ and base peak at 372 (100); Analysis: Calcd. C, 57.67; H, 4.05; Cl, 9.46; N, 7.47; S, 17.11 . Found C, 57.63; H,3.98; Cl, 9.41; N, 7.43; S, 17.06.

\section{1h 2-(Methylthio)-4-(thiophen-2-yl)-5,6-dihydroben-} zo[h]quinazoline (13): A mixture of compound 3 $(2.98 \mathrm{~g}, 0.01 \mathrm{~mol})$ and iodomethan $(1.41 \mathrm{~g}, 0.01 \mathrm{~mol})$ in ethanolic solution of sodium ethoxide (prepared from sodium metal $0.23 \mathrm{~g}, 10 \mathrm{mg}$-atom) in $20 \mathrm{ml}$ ethanol was heated under reflux for $2 \mathrm{~h}$. After acidification with acetic acid, the formed solid was collected by filtration and crystallized to give compound $\mathbf{1 3}$ in yield: 66\%; m.p: $125^{\circ} \mathrm{C}(\mathrm{MeOH})$; IR (KBr) $v_{\max }: 1592 \mathrm{~cm}^{-1}$ corresponding to $v(\mathrm{C}=\mathrm{N})$. The spectrum is also devoid of the bands corresponding to $v(\mathrm{NH})$ and $v(\mathrm{C}=\mathrm{S})$ present in the IR spectrum of $3 .{ }^{1} \mathrm{H}$ NMR $(270 \mathrm{MHz}$, $\left.\mathrm{CDCl}_{3}\right): \delta 2.60\left(\mathrm{~s}, 3 \mathrm{H}, \mathrm{SCH}_{3}\right), 2.94,3.19\left(2 \mathrm{t}, 4 \mathrm{H}, 2 \mathrm{CH}_{2}\right.$ of quinazoline ring) and 7.10-8.30 (m, 6H, Ar-H + thiophene-H), $8.38\left(\mathrm{~d}, 1 \mathrm{H}, \mathrm{C}_{5}\right.$ thiophene). $\mathrm{MS} \mathrm{m} / \mathrm{z}(\%)$ : $310\left(\mathrm{M}^{+}, 100\right.$, base peak) corresponding to the molecular formula $\mathrm{C}_{17} \mathrm{H}_{14} \mathrm{~N}_{2} \mathrm{~S}_{2}$. Analysis: Calcd. C, 65.77;
H,4.55; N, 9.02; S, 20.66. Found C, 65.73; H,4.50; N, 8.96; S, 20.61.

2.1i Ethyl 2-(4-(thiophen-2-yl)-5,6-dihydrobenzo[h]quinazolin-2-ylthio)acetate (14): A solution of compound $4(3.54 \mathrm{~g} ; 0.01 \mathrm{~mol})$ in ethanol $(50 \mathrm{ml})$ containing few drops of sulphuric acid was refluxed for $4 \mathrm{~h}$, left to cool. The separated solid was filtered off, washed with water, dried and crystallized to give compound 14 in yield: $73 \%$; m.p: $92^{\circ} \mathrm{C}(\mathrm{EtOH})$; IR $(\mathrm{KBr}) v_{\max }$ : $1744 \mathrm{~cm}^{-1}$ corresponding to $v(\mathrm{C}=\mathrm{O}$, ester $) .{ }^{1} \mathrm{H}$ NMR $\left(270 \mathrm{MHz}, \mathrm{CDCl}_{3}\right): \delta 1.27\left(\mathrm{t}, 3 \mathrm{H}, \mathrm{CH}_{3}\right), 2.93,3.18(2 \mathrm{t}$, $4 \mathrm{H}, 2 \mathrm{CH}_{2}$ of quinazoline ring $), 4.00\left(\mathrm{~s}, 2 \mathrm{H}, \mathrm{CH}_{2}\right), 4.16$ (q, 2H, $\mathrm{CH}_{2}$ ), 6.00 (s, 1H, CH-pyrimidine), $7.15(\mathrm{t}, 1 \mathrm{H}$, Ar-H ), 7.25 (t, 1H, Ar-H ), 7.37 (m, 2H, Ar-H), 7.56 (m, 2H, Ar-H ), 8.30 (d, $1 \mathrm{H}, \mathrm{C}_{5}$-thiophene). MS $\mathrm{m} / \mathrm{z}$ (\%) $382\left(\mathrm{M}^{+}, 25\right)$ corresponding the molecular formula $\mathrm{C}_{20} \mathrm{H}_{18} \mathrm{~N}_{2} \mathrm{O}_{2} \mathrm{~S}_{2}$ and base peak at 309 (100). Analysis: Calcd. C, 62.80; H, 4.74; N, 7.32; S, 16.77. Found C, 62.74; H, 4.69; N, 7.27; S,16.72.

\section{1j 2-(4-(Thiophen-2-yl)-5,6-dihydrobenzo[h]quina-} zolin-2-ylthio)acetohydrazide (15): A mixture of $\mathbf{1 4}$ $(3.82 \mathrm{~g}, 0.01 \mathrm{~mol})$ and hydrazine hydrate $(3.1 \mathrm{ml} 80 \%$, $0.05 \mathrm{~mol})$ in absolute ethanol $(20 \mathrm{ml})$ was stirred for $6 \mathrm{~h}$. The obtained solid was filtered off and crystallized to give compound 15 in yield: $69 \%$; m.p: $180^{\circ} \mathrm{C}(\mathrm{EtOH})$; IR (KBr) $v_{\max }: 3269,3154 \mathrm{~cm}^{-1}\left(\mathrm{NH}, \mathrm{NH}_{2}\right), 1653 \mathrm{~cm}^{-1}$ $(\mathrm{C}=\mathrm{O}) .{ }^{1} \mathrm{H}$ NMR $\left(270 \mathrm{MHz}, \mathrm{DMSO}-d_{6}\right): \delta 2.93,3.16$ (2t, $4 \mathrm{H}, 2 \mathrm{CH}_{2}$ of quinazoline ring), $3.91\left(\mathrm{~s}, 2 \mathrm{H}, \mathrm{CH}_{2}\right)$, 4.26 (s, 2H, $\mathrm{NH}_{2}, \mathrm{D}_{2} \mathrm{O}$ exchangeable), 7.26-7.87 (m, $6 \mathrm{H}, \mathrm{Ar}-\mathrm{H}+$ thiophene- $\mathrm{H}), 8.20\left(\mathrm{~d}, 1 \mathrm{H}, \mathrm{C}_{5}\right.$-thiophene) $9.31\left(\mathrm{~s}, 1 \mathrm{H}, \mathrm{NH}, \mathrm{D}_{2} \mathrm{O}\right.$ exchangeable). MS $\mathrm{m} / \mathrm{z}(\%)$ : $368\left(\mathrm{M}^{+}, 30\right)$ corresponding to the molecular formula $\mathrm{C}_{18} \mathrm{H}_{16} \mathrm{~N}_{4} \mathrm{OS}_{2}$ with base peak at 309. Analysis: Calcd. C, 58.67; H, 4.38; N, 15.21; S, 17.40. Found C, 58.61; $\mathrm{H}, 4.32 ; \mathrm{N}, 15.15 ; \mathrm{S}, 17.32$.

$2.1 \mathrm{k}$ Synthesis of compounds (16) and (17): A mixture of compound $15(3.7 \mathrm{~g}, 0.01 \mathrm{~mol})$ and phthalic anhydride or 3,4,5,6-tetrachlorophthalic anhydride $(0.01 \mathrm{~mol})$ in glacial acetic acid $(50 \mathrm{ml})$ was heated under reflux for $6 \mathrm{~h}$. The reaction mixture was evaporated under reduced pressure; the obtained residue was solidified with ether, filtered off, and crystallized from the proper solvent to give $\mathbf{1 6}$ and $\mathbf{1 7}$, respectively.

$2.11 \quad N-(1,3-D i o x o i s o i n d o l i n-2-y l)-2-(4-(t h i o p h e n-2-$ yl)-5,6-dihydrobenzo[h]quinazolin-2-ylthio)-acetamide

16: Yield $74 \%$; mp. $190^{\circ} \mathrm{C}\left(\mathrm{AcOH} / \mathrm{H}_{2} \mathrm{O}\right)$; IR $(\mathrm{KBr})$ $v_{\max }$ : IR spectrum of compound $\mathbf{1 6}$ demonstrated the 
presence of the bands at: $3268 \mathrm{~cm}^{-1}$ corresponding to $v(\mathrm{NH}), 1752,1672 \mathrm{~cm}^{-1}$ corresponding to $v(\mathrm{C}=\mathrm{O})$. ${ }^{1} \mathrm{H}$ NMR (270 MHz, DMSO- $\left.d_{6}\right): \delta 2.90-3.20(\mathrm{~m}, 4 \mathrm{H}$, $2 \mathrm{CH}_{2}$ of quinazoline ring), $4.01\left(\mathrm{~s}, 2 \mathrm{H}, \mathrm{CH}_{2}\right), 7.23-$ $8.40(\mathrm{~m}, 11 \mathrm{H}, \mathrm{Ar}-\mathrm{H}+$ thiophene-H) $9.85(\mathrm{~s}, 1 \mathrm{H}, \mathrm{NH})$. MS $m / z(\%): 495\left(\mathrm{M}^{+}-3 ; 1\right)$ corresponding to molecular formula $\mathrm{C}_{26} \mathrm{H}_{18} \mathrm{~N}_{4} \mathrm{O}_{3} \mathrm{~S}_{2}$, a base peaks at $\mathrm{m} / \mathrm{z} 309$ (100). Analysis: Calcd. C. 62.63; H, 3.64; N, 11.24; S, 12.86. Found: C, 62.57; H, 3.57; N, 11.18; S, 12.80 .

$2.1 \mathrm{~m} \quad N$-(4,5,6,7-tetrachloro-1,3-dioxoisoindolin-2yl)-2-(4-(thiophen-2-yl)-5,6-dihydrobenzo[h]-quinazolin2-ylthio)acetamide 17: Yield $78 \%$; mp. $150^{\circ} \mathrm{C}$ (AcOH/H2O); IR (KBr) $v_{\max }$ : spectrum of compound 17 demonstrated the presence of the bands at: $3168 \mathrm{~cm}^{-1}$ corresponding to $v(\mathrm{NH}), 1747,1713 \mathrm{~cm}^{-1}$ corresponding to $v \quad(\mathrm{C}=\mathrm{O})$. $\mathrm{MS} \mathrm{m} / z \quad(\%): 637$ $\left(\mathrm{M}^{+}+1,2\right)$, corresponding to molecular formula $\mathrm{C}_{26} \mathrm{H}_{14} \mathrm{Cl}_{4} \mathrm{~N}_{4} \mathrm{O}_{3} \mathrm{~S}_{2}$ with base peak at: $\mathrm{m} / \mathrm{z} 214$ (100). Analysis: Calcd.: C. 49.07; H, 2.22; N, 8.80; S, 10.08 . Found: C, 49,01; H, 2.16; N, 8.74; S, 10.01 .

2.1n Synthesis of compounds (18) and (19): A mixture of the acid hydrazide $15(3.82 \mathrm{~g}, 0.01 \mathrm{~mol})$ and phenylisothiocyanate or $p$-fluorobenzaldehyde $(0.01 \mathrm{~mol})$ in absolute ethanol $(50 \mathrm{ml})$ was refluxed for 3-7 h. After cooling, the separated solid was filtered off and crystallized from the proper solvent to afford the corresponding compounds $\mathbf{1 8}$ and $\mathbf{1 9}$, respectively.

2.1o N-phenyl-2-(2-(4-(thiophen-2-yl)-5,6-dihydrobenzo[h]quinazolin-2-ylthio)acetyl)hydrazinO-carbothioamide 18: Yield $60 \%$; mp. $195^{\circ} \mathrm{C}(\mathrm{EtOH})$; IR $(\mathrm{KBr})$ $v_{\max }$ : spectrum of compound $\mathbf{1 8}$ showed absorption bands at $3347,3266 \mathrm{~cm}^{-1}$ corresponding to $v(\mathrm{NH})$, $1680 \mathrm{~cm}^{-1}$ corresponding to $v(\mathrm{C}=\mathrm{O}) .{ }^{1} \mathrm{H} \quad \mathrm{NMR}$ $\left(270 \mathrm{MHz}, \mathrm{DMSO}-d_{6}\right): \delta 2.90,3.12\left(2 \mathrm{t}, 4 \mathrm{H}, 2 \mathrm{CH}_{2}\right.$ quinazoline), $4.09\left(\mathrm{~s}, 2 \mathrm{H}, \mathrm{CH}_{2}\right), 7.23-7.85(\mathrm{~m}, 10$ $\mathrm{H}, \mathrm{Ar}-\mathrm{H}+$ thiophene-H) $8.28\left(\mathrm{~d}, 1 \mathrm{H}, \mathrm{C}_{5}\right.$ thiophene $)$ 9.29, 9.66 and $10.32(3 \mathrm{~s}, 3 \mathrm{H}, 3 \mathrm{NH})$. Analysis for $\mathrm{C}_{25} \mathrm{H}_{21} \mathrm{~N}_{5} \mathrm{OS}_{3}$ (503.66): Calcd.: C. 59.62; H, 4.20; N, 13.09; S, 19.10. Found: C, 59.55; H, 4.15; N, 13.04; S, 19.05 .

2.1p N'-(4-fluorobenzylidene)-2-(4-(thiophen-2-yl)5,6-dihydrobenzo[h]quinazolin-2-ylthio)aceto-hydrazide 19: Yield 62\%; mp. $225^{\circ} \mathrm{C}(\mathrm{EtOH})$; IR (KBr) $v_{\max }$ : spectrum of compound $\mathbf{1 9}$ showed absorption bands at: $3247,1662 \mathrm{~cm}^{-1}$ corresponding to $v(\mathrm{NH})$ and $(\mathrm{C}=\mathrm{O})$, respectively. ${ }^{1} \mathrm{H}$ NMR $\left(270 \mathrm{MHz}, \mathrm{DMSO}-d_{6}\right)$ : $\delta 2.82,3.00\left(2 \mathrm{t}, 4 \mathrm{H}, 2 \mathrm{CH}_{2}\right.$ of quinazoline), $4.01(\mathrm{~s}$, $\left.2 \mathrm{H}, \mathrm{CH}_{2}\right), 7.24-8.25(\mathrm{~m}, 12 \mathrm{H}, \mathrm{Ar}-\mathrm{H}+$ thiophene$\mathrm{H}+\mathrm{CH}=\mathrm{N}), 11.62(1 \mathrm{~s}, 1 \mathrm{H}, \mathrm{NH})$. Analysis for $\mathrm{C}_{25} \mathrm{H}_{19} \mathrm{FN}_{4} \mathrm{OS}_{2}$ (474.57): Calcd.: C. 63.27; H, 4.04; N, 11.81; S, 13.51. Found: C, 63.21; H, 3.97; N, 11.74; S, 13.47 .

\subsection{Biological screening in vitro cytotoxicity}

The cytotoxicity of the newly synthesized compounds against cancer cell lines in vitro was performed with the MTT assay according to the Mosmann's method. ${ }^{20}$ The MTT assay is based on the reduction of the soluble 3-(4,5-methyl-2-thiazolyl)-2,5-diphenyl$2 \mathrm{H}$-tetrazolium bromide (MTT) into a blue-purple formazan product, mainly by mitochondrial reductase activity inside living cells. The cells used in cytotoxicity assay were cultured in RPMI 1640 medium supplemented with $10 \%$ fetal calf serum. Cells suspended in the medium $(2 \times 104 / \mathrm{mL})$ were plated in 96 -well culture plates and incubated at $37^{\circ} \mathrm{C}$ in a $5 \% \mathrm{CO}_{2}$ incubator. After $12 \mathrm{~h}$, the test sample $(2 \mu \mathrm{L})$ was added to the cells (2Ý 104) in 96-well plates and cultured at $37^{\circ} \mathrm{C}$ for 3 days.

The cultured cells were mixed with $20 \mu \mathrm{L}$ of MTT solution and incubated for $4 \mathrm{~h}$ at $37^{\circ} \mathrm{C}$. The supernatant was carefully removed from each well and $100 \mu \mathrm{L}$ of DMSO were added to each well to dissolve the formazan crystals which were formed by the cellular reduction of MTT. After mixing with a mechanical plate mixer, the absorbance of each well was measured by a microplate reader using a test wavelength of $570 \mathrm{~nm}$. The results were expressed as the $\mathrm{IC}_{50}$, which inducing a $50 \%$ inhibition of cell growth of treated cells when compared to the growth of control cells. Each experiment was performed at least 3 times. There was a good reproducibility between replicate wells with standard errors below $10 \%$.

2.2a HIV inhibitor activities (reverse transcriptase inhibitors) with therapeutic windows (cells and viruses): The established human cells, laboratoryderived virus isolates (including drug-resistant virus isolates), and low-passage clinical virus isolates used in these evaluations have previously been described in detail. ${ }^{21}$ These cells were maintained in RPMI 1640 medium supplemented with $10 \%$ fetal bovine serum, $2 \mathrm{mM}$ glutamine, penicillin $(100 \mathrm{U} / \mathrm{ml})$, and streptomycin $(100 \mu \mathrm{g} / \mathrm{ml})$. Fresh human cells were obtained from the American Red Cross (Baltimore, Md.).

2.2b Antiviral and cross-resistance assays: The inhibitory activities of the compounds against HIV were 
evaluated by microtiter anti-HIV assays with CEMSS cells or fresh human peripheral blood mononuclear cells (PBMCs); these assays quantify the ability of a compound to inhibit HIV-induced cell killing or HIV replication. Quantification was performed by the tetrazolium dye XTT assay (CEM-SS, 174×CEM, MT2, and AA5 cell-based assays), which is metabolized to a coloured formazan product by viable cells, RT assay (U937- and PBMC-based assays), and/or p24 enzymelinked immunosorbent assay (monocyte-macrophage assays). Antiviral and toxicity data are reported as the quantity of drug required for inhibiting virus-induced cell killing or virus production by $50 \%\left(\mathrm{EC}_{50}\right)$.

\section{2c In vitro assays of anti-HIV activity: Purified RT} assays of the newly synthesized compounds were tested for RT inhibitory activity against purified recombinant HIV-1 RT using the cell-free Quan-T-RT assay system (Amersham Corp., Arlington Heights, IL), which utilizes the scintillation proximity assay (SPA) principle, as described in detail. ${ }^{22}$

In the assay, a DNA/RNA template is bound to SPA beads via a iotin/streptavidin linkage. The primer DNA is a 16-mer oligo(T), which has been annealed to a poly(rA) template. The primer-template is bound to a streptavidin-coated SPA bead. $\left[{ }^{3} \mathrm{H}\right] \mathrm{TTP}$ (thymidine -5 '- triphosphate) is incorporated into the primer by reverse transcription. In brief, $\left[{ }^{3} \mathrm{H}\right] \mathrm{TTP}$, at a final concentration of $0.5 \mu \mathrm{Ci} / \mathrm{sample}$, was diluted in RT assay buffer (49.5 mM Tris-HCl, pH 8.0, $80 \mathrm{mM} \mathrm{KCl,} 10 \mathrm{mM}$ $\mathrm{MgCl}_{2}, 10 \mathrm{mM}$ dithiothreitol, $2.5 \mathrm{mM}$ EDTA, $0.05 \%$ Nonidet P-40) and added to annealed DNA/RNA bound to SPA beads. The compound being tested was added to the reaction mixture at $0.001-100 \mu \mathrm{M}$ concentrations. Addition of $10 \mathrm{mU}$ of recombinant HIV RT and incubation at $37^{\circ} \mathrm{C}$ for $1 \mathrm{~h}$ resulted in the extension of the primer by incorporation of $\left[{ }^{3} \mathrm{H}\right] \mathrm{TTP}$. The reaction was stopped by addition of $0.2 \mathrm{ml}$ of $120 \mathrm{mM}$ EDTA. The samples were counted in an open window using a Beckman LS 7600 instrument and $\mathrm{IC}_{50[\mathrm{RT}]}$ values (concentration at which the compound inhibits recombinant RT by $50 \%$ ) were calculated by comparing the measurements to an untreated.

\section{2d Hepatitis $C$ virus (HCV) NS3-4A protease} inhibitor activities: The success of human immunodeficiency virus (HIV) protease inhibitors in treating HIV-infected patients has raised the hope that inhibitors of HCV NS3-4A serine protease could also become effective therapy options for hepatitis $\mathrm{C}$ patients.

Parental Huh-7 and HepG2 cells were cultured in Dulbecco's modified Eagle's medium (DMEM) containing $10 \%$ heat-inactivated fetal bovine serum (FBS), $2 \mathrm{mM}$ L-glutamine, and non-essential amino acids. Stable Huh-7 cells containing the self-replicating, sub-genomic HCV replicon, which was identical in sequence to the I377neo/NS3-3'/wt replicon described by Lohmann et al. ${ }^{23}$ were selected and maintained in the presence of $0.25 \mathrm{mg} / \mathrm{ml} \mathrm{G} 418$ (Invitrogen, Carlsbad, $\mathrm{CA}$ ) and were used for anti-HCV assays. Peripheral blood mononuclear cells (PBMC) were isolated from fresh donor blood and cultured in RPMI-1640 medium (JRH Biosciences).

2.2e Determination of anti-HCV activity and cytotoxicity: Determination of 50\% inhibitory concentration $\left(\mathrm{IC}_{50}\right), 90 \%$ inhibitory concentration $\left(\mathrm{IC}_{90}\right)$, and $50 \%$ cytotoxic concentration $\left(\mathrm{CC}_{50}\right)$ of all the tested compounds in $\mathrm{HCV}$ replicon cells was performed as described. Pre-clinical profile of VX-950, a potent, selective, and orally bioavailable inhibitor of hepatitis $\mathrm{C}$ virus (NS3-4A serine protease). Briefly, $1 \times 10^{4}$ replicon cells per well were plated in 96-well plates. On the following day, replicon cells were incubated at $37^{\circ} \mathrm{C}$ for the indicated period of time with antiviral agents serially diluted in DMEM plus 2\% FBS and $0.5 \%$ dimethylsulphoxide (DMSO). Total cellular RNA was extracted using an RNeasy-96 kit (QIAGEN, Valencia, CA), and the copy number of HCV RNA was determined using a quantitative RT-PCR (QRT-PCR) assay. Combination of a hepatitis $\mathrm{C}$ virus NS3-NS4A protease inhibitor and alpha interferon synergistically inhibits viral RNA replication and facilitates viral RNA clearance in replicon cells. Each datum point represents the average of five replicates in cell culture. The cytotoxicity of the tested compounds was measured under the same experimental settings using a tetrazolium (MTS)-based cell viability assay. For the cytotoxicity assay with human hepatocyte cell lines, $1 \times 10^{4}$ parental Huh-7 cells per well or $4 \times 10^{4}$ HepG2 cells per well were used. To determine cytotoxicity of the tested compound against resting PBMC, $1 \times 10^{5}$ cells per well were incubated with the tested compound in RPMI-1640 medium (no serum) for $48 \mathrm{~h}$, and the cell viability was determined by the MTS-based assay. To determine cytotoxicity of the tested compound against proliferating PBMC, $1 \times 10^{5}$ cells per well in RPMI-1640 medium were added to a 96-well plate, which was pre-coated with anti-human CD3 antibody (Accurate Chemical and Scientific Corporation, Westbury, NY). The cells were incubated with the tested compound and anti-human CD28 antibody (Pharmingen/BD Biosciences, San Jose, CA) for $72 \mathrm{~h}$ at $37^{\circ} \mathrm{C}$, and the cell growth was determined by $\left[{ }^{3} \mathrm{H}\right]$ thymidine update between the $48^{\text {th }}$ and $72^{\text {nd }} \mathrm{h}$. 
$\underbrace{(11}_{1}$

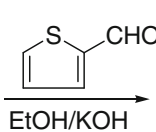

$\mathrm{EtOH} / \mathrm{KOH}$
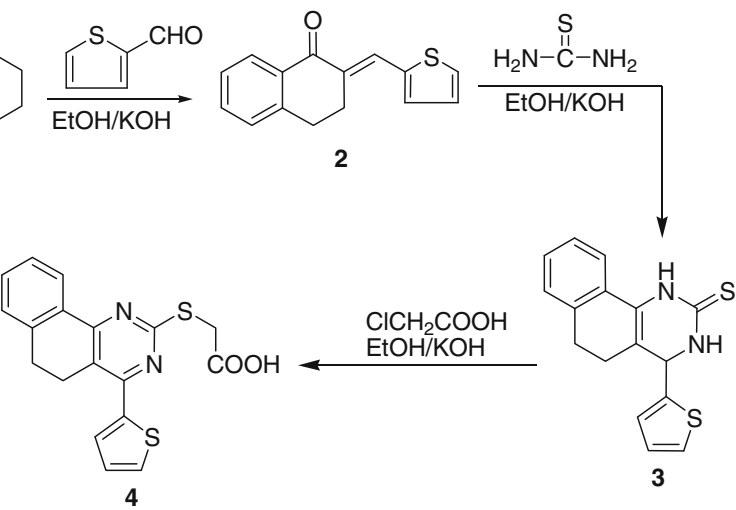

Scheme 1.

\section{Results and discussion}

\subsection{Chemistry}

In our previous work, ${ }^{6-19}$ we reported the synthesis and a preliminary biological activity screening of several thiopyrimidine derivatives based on arylmethylene 2, 4-thiophen-2-yl-3,4,5,6-tetrahydro- $1 \mathrm{H}$ benzo[h]quinazoline-2-thione (3) and 2-(4-(thiophen2-yl)-5,6-dihydrobenzo[h]quinazolin-2-ylthio) acetic acid (4), which were synthesized according to the literature procedures ${ }^{24}$ (scheme 1).

Arylmethylene 2 was allowed to react with guanidine hydrochloride in ethanolic potassium hydroxide to yield the corresponding 4-thiophen-2-yl-5,6-dihydrobenzo[h]quinazolin-2-ylamine (5), which was reacted with 3,4,5,6-tetrachlorophthalic anhydride under fusion to yield 4,5,6,7-tetrachloro-2-(4-thiophen-2-yl-3,4,5,6tetrahydrobenzo[h]quinazolin-2-yl)isoindole-1,3-dione (6). Also, amino-pyrimidine 5 was treated with acetic anhydride or methyl sulphonylchloride to afford the corresponding N-(4-thiophen-2-yl-5,6-dihydrobenzo[h] quinazolin-2-yl)-acetamide (7) and N-(4-thiophen2-yl-5,6-dihydro-benzo[h]quinazolin-2-yl)methanesulphonamide (8), respectively (scheme 2 ).

In addition, thioxopyrimidine $\mathbf{3}$ was reacted with chlorodiethyl ether in the presence of sodium hydride afforded 4-thiophen-2-yl-5,6-dihydro-1H-benzo[h]quinazoline-2-thione (9) rather than the $S$-alkylated form 10. 2-Thiopyrimidine 3 underwent alkylation giving $S$ alkylation or $N$-alkylation depending on the reaction conditions. So, when compound $\mathbf{3}$ was refluxed in acetylchloride or chloro-acetylchloride afforded the corresponding 1-(4-thiophen-2-yl-2-thioxo-1,4,5,6tetrahydro-2H-benzo[h]-quinazolin-3-yl)ethanone (11) and S-[4-(thiophen-2-yl)-3,4,5,6-tetrahydrobenzo[h]quinazolin-2-yl] 2-chloroethanethioate (12), respectively. On the other hand, compound $\mathbf{3}$ was reacted with methyl iodide to afford 2-methylsulfanyl-4-thiophen2-yl-5,6-dihydrobenzo[h]quinazoline (13) (scheme 3).

On the other hand, When esterification of the carboxylic acid derivative 4 with refluxed ethanol in the presence of concentrated sulphuric acid afforded ethyl 2-(4-(thiophen-2-yl)-5,6-dihydrobenzo[h]-quinazolin-2ylthio)acetate (14), which was treated with hydrazine hydrate in ethanol to produce (4-thiophen-2-yl-3,4,5,

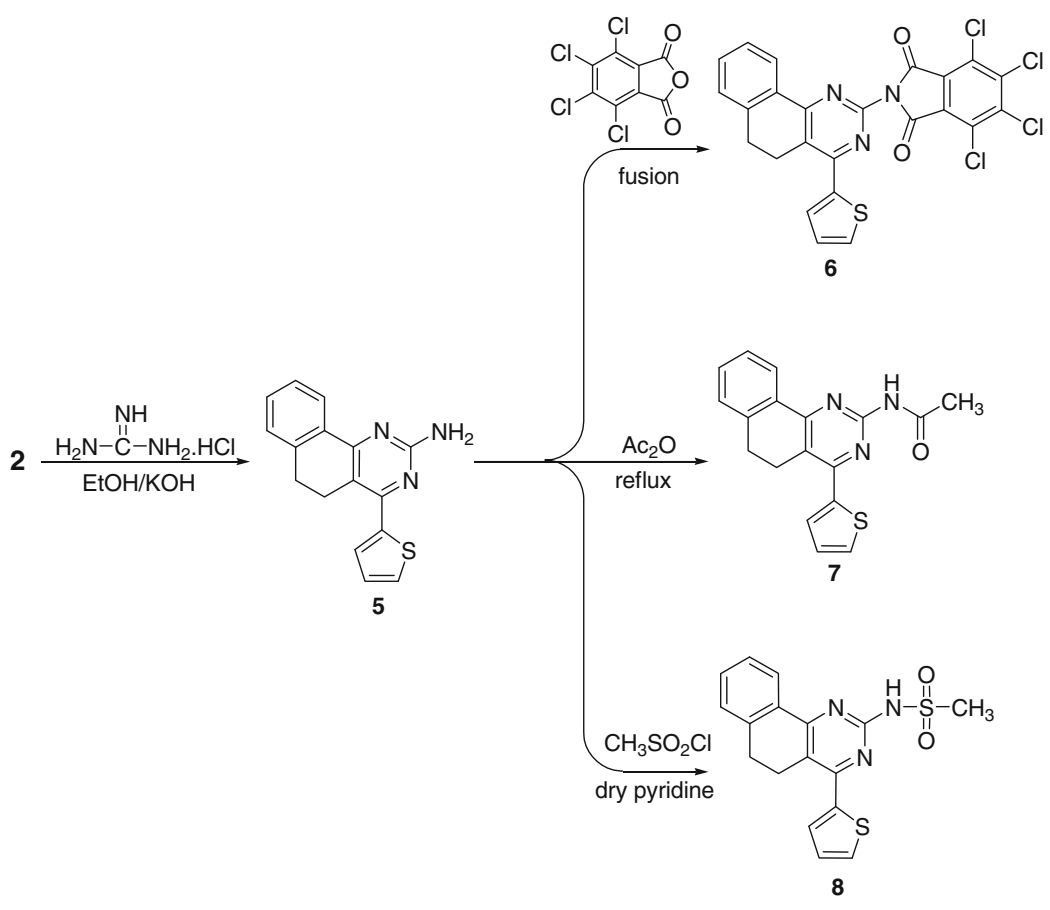

Scheme 2. 


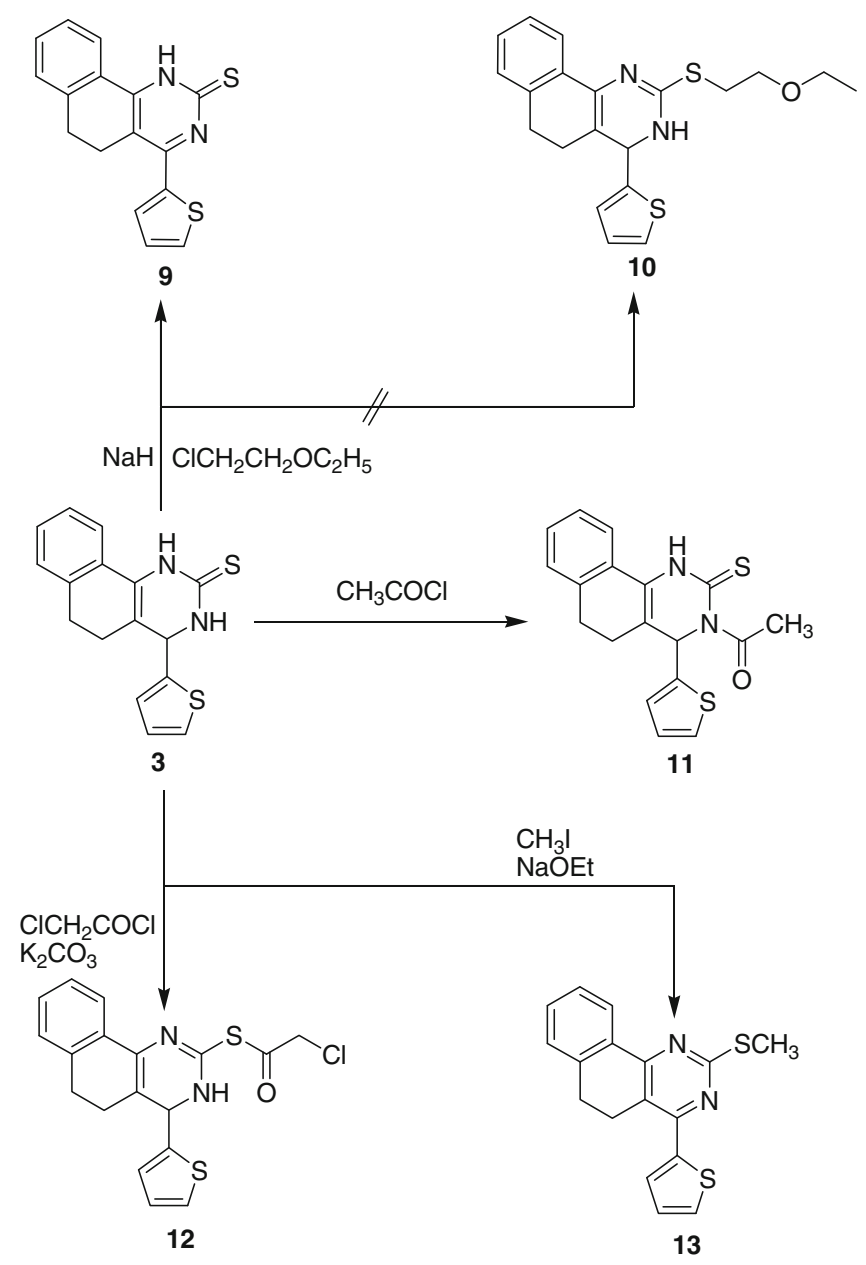

Scheme 3. 6-tetrahydrobenzo[h] quinazolin-2-ylsulfanyl)-acetohydrazide 15. The reaction of the hydrazide $\mathbf{1 5}$ with phthalic anhydride or 3,4,5,6-tetrachlorophthalic anhydride in glacial acetic acid furnished pyrrolobenzene derivatives 16 and 17, respectively. One the other hand, treatment of hydrazide $\mathbf{1 5}$ with phenyl isothiocyanate or $p$-florobenzaldehyde in ethanol under reflux afforded thiosemicarbazide 18 and hydrazone 19, respectively (scheme 4).

\subsection{Biological activity}

Some of the newly synthesized compounds were tested for their cytotoxicity on different cancer cell lines and virus. The obtained results were summarized in the following tables $1-4$.

3.2a Anticancer activity: Regarding the anticancer activity careful examining of the data obtained from table 1 , compounds $2,3,4,6,9,11,12,13,14,15$, 16 and 19 showed potent cytotoxic activity against Leukemia (HL60, U937 and K562), melanoma (G361 and SK-MEL-28), neuroblast (GOTO and NB-1) and normal cell carcinoma (W138) cell lines. The most active compounds are $\mathbf{2 , 6 , 9 , 1 3 , 1 5}$ and $\mathbf{1 9}$. It is worth to mention that most of the tested compounds showed potent activities where they have minimal $\mathrm{IC}_{50}$. From table 2, the same compounds showed cytotoxic activity against cervical carcinoma (KB), CNS (SF-268), colon,

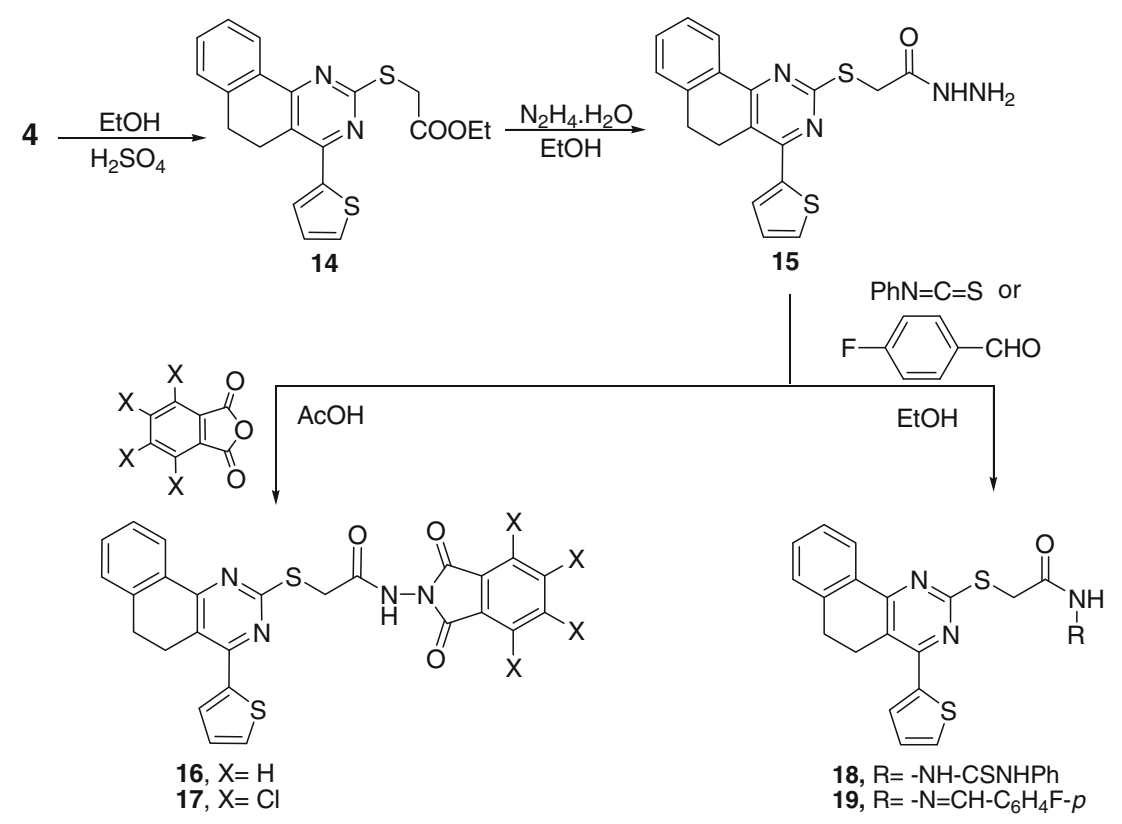

Scheme 4. 
Table 1. The activities of the tested compounds on some cancer cell lines.

\begin{tabular}{|c|c|c|c|c|c|c|c|c|}
\hline \multirow[b]{3}{*}{ Product } & \multicolumn{8}{|c|}{ IC50 } \\
\hline & \multicolumn{3}{|c|}{ Leukaemia } & \multicolumn{2}{|c|}{ Melanoma } & \multicolumn{2}{|c|}{ Neuroblast } & \multirow{2}{*}{$\begin{array}{c}\begin{array}{c}\text { Normal cell } \\
\text { carcinoma }\end{array} \\
\text { W138 }\end{array}$} \\
\hline & HL60 & U937 & K562 & G361 & SK-MEL-28 & GOTO & NB-1 & \\
\hline \multirow[t]{2}{*}{2} & 5.4 & 4.4 & 1.4 & 1.5 & 5.2 & 7.5 & 4.7 & 6.4 \\
\hline & E-03 & E-03 & E-03 & E-03 & E-03 & E-03 & E-03 & E-03 \\
\hline \multirow[t]{2}{*}{3} & 3.5 & 6.4 & 6.4 & 6.8 & 7.9 & 9.7 & 9.7 & 9.7 \\
\hline & E-03 & E-03 & E-03 & E-03 & E-03 & E-03 & E-03 & E-03 \\
\hline \multirow[t]{2}{*}{4} & 8.3 & 8.7 & 7.2 & 8.8 & 7.7 & 6.6 & 8.5 & 9.8 \\
\hline & E-03 & E-03 & E-03 & E-03 & E-03 & E-03 & E-03 & E-03 \\
\hline \multirow[t]{2}{*}{6} & 8.9 & 9.0 & 8.7 & 7.9 & 9.8 & 8.7 & 4.3 & - \\
\hline & E-03 & E-03 & E-03 & E-03 & E-03 & E-03 & E-03 & \\
\hline \multirow[t]{2}{*}{9} & 2.4 & 3.5 & 7.4 & 7.3 & 4.2 & 4.7 & 3.1 & 8.4 \\
\hline & E-03 & E-03 & E-03 & E-03 & E-03 & E-03 & E-03 & E-03 \\
\hline \multirow[t]{2}{*}{11} & 6.4 & 6.4 & 5.7 & 9.7 & 6.5 & 4.5 & 8.5 & 6.8 \\
\hline & E-03 & E-03 & E-03 & E-03 & E-03 & E-03 & E-03 & E-03 \\
\hline \multirow[t]{2}{*}{12} & 7.8 & 9.8 & 8.0 & 9.7 & 9.7 & 9.7 & 6.8 & 9.7 \\
\hline & E-03 & E-03 & E-03 & E-03 & E-03 & E-03 & E-03 & E-03 \\
\hline \multirow[t]{2}{*}{13} & 8.8 & 8.9 & 7.0 & 7.8 & 8.0 & 7.6 & 3.2 & 8.7 \\
\hline & E-03 & E-03 & E-03 & E-03 & E-03 & E-03 & E-03 & E-03 \\
\hline \multirow[t]{2}{*}{14} & 6.7 & 9.8 & 9.8 & 7.6 & 9.0 & 9.8 & 7.6 & 7.6 \\
\hline & E-03 & E-03 & E-03 & E-03 & E-03 & E-03 & E-03 & E-03 \\
\hline \multirow[t]{2}{*}{15} & 6.4 & 7.7 & 7.9 & 4.0 & 2.8 & 9.2 & 8.7 & 1.4 \\
\hline & E-03 & E-03 & E-03 & E-03 & E-03 & E-03 & E-03 & E-03 \\
\hline \multirow[t]{2}{*}{16} & 7.8 & 9.8 & 7.6 & 7.5 & 8.3 & 6.4 & 9.6 & 9.0 \\
\hline & E-03 & E-03 & E-03 & E-03 & E-03 & E-03 & E-03 & E-03 \\
\hline \multirow[t]{2}{*}{19} & 5.3 & 5.3 & 3.5 & 3.5 & 5.1 & 3.2 & 6.8 & 7.9 \\
\hline & E-03 & E-03 & E-03 & E-03 & E-03 & E-03 & E-03 & E-03 \\
\hline
\end{tabular}

adenocarcinoma (RKOP27), ovarial carcinoma (SKOV3 ) and non-small-cell lung cancer (NCI H-460) cancer cell lines. The most active compounds are $\mathbf{2 , 4}$ and 11. Also the tested compounds showed potent activities where they have minimal $\mathrm{IC}_{50}$.

Table 2. Cytotoxicity of some new compounds on some new cancer cell lines.

\begin{tabular}{lccccc}
\hline & \multicolumn{5}{c}{$\mathrm{IC}_{50}$} \\
\cline { 2 - 6 } Product & KB & SK OV-3 & SF-268 & NCl H460 & RKOP27 \\
\hline $\mathbf{2}$ & 4.9 E-03 & 5.9 E-03 & 3.0 E-03 & 2.4 E-03 & 3.3 E-03 \\
$\mathbf{3}$ & 5.6 E-03 & 5.4 E-03 & 6.7 E-03 & 7.6 E-03 & 9.8 E-03 \\
$\mathbf{4}$ & 3.9 E-03 & 4.7 E-03 & 5.8 E-03 & 5.9 E-03 & 5.0 E-03 \\
$\mathbf{6}$ & 9.0 E-03 & 9.0 E-03 & 6.0 E-03 & 9.6 E-03 & 9.5 E-03 \\
$\mathbf{9}$ & 6.5 E-03 & 9.8 E-03 & 9.4 E-03 & 4.9 E-03 & 6.5 E-03 \\
$\mathbf{1 1}$ & 3.0 E-03 & 4.0 E-03 & 4.0 E-03 & 4.8 E-03 & 4.9 E-03 \\
$\mathbf{1 2}$ & 7.8 E-03 & 9.8 E-03 & 7.6 E-03 & 6.6 E-03 & 8.7 E-03 \\
$\mathbf{1 3}$ & 8.8 E-03 & 6.9 E-03 & 5.0 E-03 & 6.0 E-03 & 6.0 E-03 \\
$\mathbf{1 4}$ & 7.8 E-03 & 5.4 E-03 & 5.4 E-03 & 6.7 E-03 & 9.0 E-03 \\
$\mathbf{1 5}$ & 4.3 E-03 & 9.8 E-03 & 5.6 E-03 & 7.6 E-03 & 9.8 E-03 \\
$\mathbf{1 6}$ & 7.8 E-03 & 9.4 E-03 & 7.8 E-03 & 6.7 E-03 & 9.0 E-03 \\
$\mathbf{1 9}$ & 4.9 E-03 & 9.8 E-03 & 7.6 E-03 & 6.5 E-03 & 8.7 E-03
\end{tabular}

3.2b Anti-HIV activity: Regarding the anti-HIV activities, compounds $2,3,4,6,9,11,12,13,14,15$, 16 and 19 showed potent anti-HIV activities and the descending order of the activity is $\mathbf{6}, \mathbf{1 3}, \mathbf{3}, \mathbf{1 2}, \mathbf{1 9}$, 14, 19, 15, 2, 9, 16, 4 and 11 (table 3). Concerning the mechanism of action as anti-HIV, these compounds were reverse transcriptase inhibitors.

Table 3. HIV inhibitor activities (reverse transcriptase inhibitors) with therapeutic windows.

\begin{tabular}{lccc}
\hline Product & $\mathrm{EC}_{50} / \mathrm{Mm}$ & $\mathrm{IC}_{50} / \mu \mathrm{M}$ & Therapeutic index \\
\hline $\mathbf{2}$ & 0.00525 & 6.1 & 33000 \\
$\mathbf{3}$ & 0.00722 & 2.6 & 32122 \\
$\mathbf{4}$ & 0,00084 & 17.4 & 784,532 \\
$\mathbf{6}$ & $2.44 \times 10^{-4}$ & 2.11 & $1.89 \times 10^{5}$ \\
$\mathbf{9}$ & 0.00778 & 8.1 & 44432 \\
$\mathbf{1 1}$ & $5.44 \times 10^{-4}$ & 22.6 & $8.34 \times 10^{5}$ \\
$\mathbf{1 2}$ & $3.71 \times 10^{-4}$ & 2.9 & $3.66 \times 10^{5}$ \\
$\mathbf{1 3}$ & $6.24 \times 10^{-5}$ & 2.33 & $2.15 \times 10^{6}$ \\
$\mathbf{1 4}$ & $10^{-4}$ & 4.4 & $2.33 \times 10^{5}$ \\
$\mathbf{1 5}$ & 0.00871 & 5.6 & 92160 \\
$\mathbf{1 6}$ & 2.3 & 16.2 & 40 \\
$\mathbf{1 9}$ & 0.00691 & 3.4 & 103654 \\
\hline
\end{tabular}


Table 4. Hepatitis C virus (HCV) NS3-4A protease inhibitor activities.

\begin{tabular}{lcrcc}
\hline Product & $\begin{array}{c}\mathrm{IC}_{50}( \pm \mathrm{SD}) \mu \mathrm{M} \\
\text { after } 48 \mathrm{~h}\end{array}$ & $\begin{array}{c}\mathrm{IC}_{90}( \pm \mathrm{SD}) \mu \mathrm{M} \\
\text { after } 48 \mathrm{~h}\end{array}$ & $\mathrm{CC} 50( \pm \mathrm{SD}) \mu \mathrm{M}$ & $\begin{array}{c}\text { Window } \\
\text { index }\end{array}$ \\
\hline $\mathbf{2}$ & $0.318 \pm 0.042$ & $2.78 \pm 0.077$ & $2738 \pm 8.5$ & 2201.450 \\
$\mathbf{4}$ & $0.188 \pm 0.022$ & $0.501 \pm 0.033$ & $516 \pm 4.5$ & 2723.450 \\
$\mathbf{1 1}$ & $0.288 \pm 0.031$ & $1.89 \pm 0.066$ & $1788 \pm 6.5$ & 2399.600 \\
$\mathbf{1 4}$ & $0.244 \pm 0.035$ & $0.897 \pm 0.053$ & $716 \pm 6.8$ & 2578.500 \\
$\mathbf{1 6}$ & $0.145 \pm 0.020$ & $0.301 \pm 0.021$ & $215 \pm 3.2$ & 2829.540 \\
\hline
\end{tabular}

3.2c Anti-HCV activity: Regarding the anti-HCV activities, compounds 2, 4, 11, 14, and 16 showed potent anti-HCV activities and the descending order of the activity is 16, 4, 14, 11 and 2 (table 4). Concerning the mechanism of action as anti-HCV, these compounds were HCV NS3-4A protease inhibitor activities.

\subsection{Structure activity relationship (SAR)}

- From tables 1 and 2, all the tested compounds showed activity against leukemia (HL60, U937 and K562), melanoma (G361 and SK-MEL-28), neuroblast (GOTO and NB-1), normal cell carcinoma (W138), cervical carcinoma (KB), CNS (SF-268), colon adenocarcinoma (RKOP27), ovarial carcinoma (SKOV-3) and non-small-cell lung cancer (NCI H460) cancer cell lines. In addition, the presence of pyrimidine ring fused with tetrahydronaphthaline and carboxylic acid as substituted due to the increase the anticancer activity.

- From tables 3 and 4, regarding the anti-HIV and anti$\mathrm{HCV}$ activities fusion of thiophene to the pyrimidine nucleus and attaching of opened chain nucleus to the central atom greatly intensify the activity.

- Compounds 2, 4, 6, 11, and 16 showed better activity compared to other derivatives due to their content of multi-basic centres able to facile hydrogen bonding with receptor sites and improve their planarity character that enable them to inter chelae with DNA and RNA.

- Compound 16 showed higher biological activity than 17, may be due to the presence of chlorine atoms that deform the planarity of the molecule and hinder the interchlation with target receptor.

\section{Conclusion}

A series of dihydrobenzo[h]quinazoline derivatives 5-19 were synthesized using arylmethylene 2, thiopyrimidine 3 and 2-(4-(thiophen-2-yl)-5,6dihydrobenzo[h]quinazolin-2-ylthio) acetic acid (4) as a starting materials. The biological screening showed that many of these compounds have good anticancer and antiviral activities.

\section{Acknowledgements}

The Authors thank the Deanship of Scientific Research at King Saud University for funding the work through the research group project No. RGP-VPP-099.

\section{References}

1. Zigeuner G, Lintschinger W B, Fuchsgruber A and Kollmann K 1976 Monatsh. Chem. 107171

2. Mathes R A and Stewart F D 1950 J. Am. Chem. Soc. 72 1879

3. Moustafa H M, Khodairy A and El-Saghier A M M 2003 Phosphorus Sulfur 1781211

4. Bakhite E A, Abdel-Rahman A and Al-Taifi E A 2004 Phosphorus Sulfur 179513

5. Pathak U S, Devani M B, Shishoo C J, Kulkarni R R, Rakholia V M, Bhadti V S, Ananthan S, Dave M G and Shah V A 1986 Indian J. Chem. B. 25B 489

6. Amr A E, Hegab M I, Ibrahim A A and Abdalah M M 2003 Monatsh. Chem. 1341395

7. Amr A E and Abdulla M M 2002 Indian J. Heterocycl. Chem. 12129

8. Nehad A A, Amr A E and Alhusien A I 2007 Monatsh. Chem. 138559

9. Amr A E, Nermien M S and Abdulla M M 2007 Monatsh. Chem. 138699

10. Amr A E, Ashraf M M, Salwa F M, Nagla A A and Hammam A G 2006 Bioorg. Med. Chem. 145481

11. Amr A E, Sayed H H and Abdulla M M 2005 Arch. Pharm. Chem. Life Sci. 338433

12. Hassan S S M, Abou-Ghalia M H, Amr A E and Mohamed A H K 2003 Talanta 6081

13. Hassan S S M, Abou-Ghalia M H, Amr A E and Mohamed A H K 2003 Anal. Chem. Acta. 4829

14. Amr A E, Nehad A A and Abdalla M M 2006 Bioorg. Med. Chem. 14373

15. Amr A E and Abdalla M M 2006 Bioorg. Med. Chem. 144341

16. Amr A E, Nermien M S, Abdalla M M and Bakr F A 2009 Eur. J. Med. Chem. 44725

17. Amr A E, Korany A A and Abdalla M M 2009 Eur. J. Med. Chem. 44901 
18. Amr A E, Abo-Ghalia M H and Abdalla M M 2007 Arch. Pharm. Chem. Life Sci. 340304

19. Issa M F, Amr A E, Nermien M S and Abdalla M M 2008 Arch. Pharm. Chem. Life Sci. 341174

20. Jr Buckheit R W, Kinjerski $\mathrm{T}$ L, Fliakas-Boltz V, Russell J D, Stup T L, Pallansch L A, Brouwer W G, Dao D C, Harrison W A, Schultz R J, Bader J P and Yang S S 1995 Antimicrob. Agents Chemother. 39 2718
21. Zarling J M, Moran P A, Haffar O, Diegel M, Myers D E, Kuelbeck V, Ledbetter J A and Uckun F M 1991 Int. J. Immunopharmacol. 1363

22. Lin K, Kwong A D and Lin C 2004 Antimicrob. Agents Chemother $\mathbf{4 8} 4784$

23. Lohmann V, Korner F, Koch J, Herian U, Theilmann L and Bartenschlager R 1999 Science 285110

24. Mohamed S F, Thabet H Kh, Mustafa E E, Abdalla M M and Shafik S H 2009 World J. Chem. 4100 